\title{
Moderne diskoerse in die teologie vandag
}

\author{
Author: \\ J.H. van Wyk ${ }^{1}$ \\ Affiliation: \\ ${ }^{1}$ Eenheid vir Reformatoriese \\ Teologie, Noordwes- \\ Universiteit, South Africa \\ Correspondence to: \\ J.H. van Wyk \\ Email: \\ amiejanvw@gmail.com \\ Postal address: \\ PO Box 11692, Silverlakes \\ 0054, South Africa \\ Dates: \\ Received: 12 Apr. 2011 \\ Accepted: 19 Sept. 2012 \\ Published: 23 May 2013 \\ How to cite this article: \\ Van Wyk, J.H., 2013, \\ 'Moderne diskoerse in die \\ teologie vandag', In die \\ Skriflig/In Luce Verbi 47(1), \\ Art. \#718, 9 pages. \\ http://dx.doi.org/10.4102/ \\ ids.v47i1.718
}

\section{Copyright:}

(C) 2013. The Authors.

Licensee: AOSIS

OpenJournals. This work

is licensed under the

Creative Commons

Attribution License.

Read online:
In hierdie artikel word aandag gevra vir enkele moderne diskoerse in die teologie vandag. Volgens die outeur staan die vrae oor God, Jesus, die mens en die aarde in die sentrum van belangstelling en oorheers dit in 'n groot mate die teologiese debat. Die opkoms van die moderne aggressiewe ateïsme, die wetenskaplike navorsing oor die historiese Jesus, die groeiende vrae oor die mens en die menslike samelewing, asook die dreigende ekologiese krisis op aarde, sorg vir nuwe debatte van ongekende omvang. Die outeur bespreek hierdie debatte oorsigtelik, met kritiek waar nodig, en sluit af met enkele rigtingwysers van wat hy as 'goeie teologie' verstaan.

Modern discourses in theology today. In this article attention is paid to some modern discourses in theology today. According to the author the questions about God, Jesus, man and the earth are in the centre of interest and to a large extent dominate the theological debate. The rise of modern aggressive atheism, the scientific research on the historic Jesus, the growing questions about man and human society as well as the threatening ecological crisis on earth, provide new discourses of unparalleled magnitude. The author provides a broad summary of these discourses, with criticism where necessary, and concludes with some indicators of his view what can be called 'good theology'.

\section{Inleiding}

Dat daar iets van 'n 'oerknal' in die moderne teologiese wêreld plaasgevind het, kan sonder veel moeite aangetoon word. As John Stott in 1990 oor Issues facing Christians Today nadink, gee hy 'n oorsig van die moderne (veral etiese) problematiek: die wapenwedloop, die omgewing, ekonomiese ongelykheid, menseregte, werkloosheid, industriële verhoudings, rasseverhoudings, armoede, huwelik en egskeiding, aborsie en homoseksuele verhoudings. In sy boek A new Kind of Christiantiy (2010), ondersoek Brian McLaren weer meer teologiese kwessies soos die narratiewe vraag, die gesagsvraag, die Godsvraag, die Jesusvraag, die evangelievraag, die kerkvraag, die seksvraag, die toekomsvraag, die pluralisme-vraag en die wat-doen-ons-nou-vraag. ${ }^{1}$ Uiteraard is dit onhaalbaar om in een artikel al bogenoemde onderwerpe sinvol aan die orde te stel en daarom moet daar noodwendig 'n seleksie plaasvind. Dit blyk duidelik dat ten minste vier temas vandag in die brandpunt van teologiese belangstelling en diskussie staan, naamlik God, Jesus, die mens en die aarde. Hierdie vier diskoerse (of debatte), naamlik die diskoers oor God, die diskoers oor Jesus, die diskoers oor die mens (en die menslike samelewing) en die diskoers oor die aarde (of die omgewing), oorheers vandag in 'n groot mate die teologiese wêreld, asook in Suid-Afrika. Hierdie vier temas sal onder die loep geneem en soms met persoonlike ervarings ingekleur word. Die artikel word afgesluit met enkele opmerkings oor die kenmerke van dit wat, volgens die skrywer, 'goeie teologie' genoem sou kon word.

\section{Moderne diskoerse Die diskoers oor God}

Die vraag na God kan sonder meer as die belangrikste vraag in die teologie beskou word. Die Geneefse kerkhervormer Johannes Calvyn, begin sy Geneefse Kategismus (1542) met die vraag, naamlik wat die belangrikste doel van die mens se lewe is en antwoord dan daarop met: Om God te leer ken deur wie die mens geskape is. Sy beroemde Institusie (1559) sluit hierby aan, want die eerste sin daarvan lui dat die eindtotaal van ons wysheid bestaan uit die kennis van God en, voeg hy by, die kennis van onsself (Inst, 1.1.1). Daarom is die Rooms-Katolieke teoloog, Hans Küng, heeltemal korrek om sy boeiende boek Die Kirche (1967), te begin met die opmerking dat die vraag na God belangriker is as die vraag na die kerk.

1.Wat Suid-Afrika betref, kan ook na die werk van De Gruchy (1991, 2011) verwys word. Vergelyk ook die kritiese boek van Kennedy (2006:252-260) waarin hy die Bybelse boodskap reduseer tot (1) geloof in God en (2) navolging van die goeie mens Jesus. 
Ons gaan in hierdie onderafdeling fokus op die diskoers wat deur ateïste aan die orde gestel word - 'n debat wat in die wêreld sowel as in Suid-Afrika al groter afmetings aanneem en in intensiteit groei.

My eerste ervaring hiervan was in 1969 tydens Amsterdamse studietyd. Daar is by geleentheid 'n TV-onderhoud met die bekende Britse ateïstiese filosoof, Bertrand Russell (1872-1970), uitgesaai. Toe aan hom gevra is wat hy aan God sou sê indien hy na sy dood ontdek dat daar tog 'n God is, het hy dadelik geantwoord met: 'Not enough evidence.' Daarmee erken Russell die vooronderstellings van ateïsme, naamlik rasionalisme en positivisme. Alles wat nie verstandelik deursigtig is nie en nie (natuur-)wetenskaplik geverifieer kan word nie, is vir die mens onaanvaarbaar en 'n bygeloof. ${ }^{2}$ Ons kom later hierop terug. (Hiermee is natuurlik een van die groot dispuutpunte van die moderne debat aangeraak wat oor die verhouding tussen geloof en wete/verstand, skepping en evolusie, teologie en natuurwetenskap handel maar dis 'n verhaal van sy eie.)

My jongste ervaring van ateïsme was redelik onlangs. 'n Jaar of wat gelede het ek onverwags 'n reaksie per epos van 'n onbekende persoon ontvang na aanleiding van 'n artikel van my wat in die dagblad Beeld verskyn het. Uiteindelik blyk dit dat dié persoon, met die naam Armando Pellencin, as Katoliek opgegroei het, maar tans ' $\mathrm{n}$ volslae ateïs is, soos duidelik uit sy boek Die saak teen God (2007) blyk. Na twee jaar het hy ons eposdebat gestaak, maar daartydens tog aan my die vraag gestel: Glo jy nog in God? Met die suggestie dat geen intellektuele persoon of iemand wat erns maak met die resultate van die (natuur-)wetenskap, langer in God kan glo nie. Die bestaan van God is immers onbewysbaar.

Die kritiese vraag van Pellencin het my uitgedaag tot ' $n$ nuwe selfverantwoording van my christelike geloof en 'n dieper nadenke oor die vraag na God. Wié is Hy? Hoé is Hy? Wáár is Hy? Wat doén Hy? Hoé doen Hy wat Hy doen? Wáárom doen Hy wat Hy doen? Daarom het ek die afgelope aantal jare baie tyd aan boeke oor die Godsvraag en die ateïsme bestee. ${ }^{3}$

Die opkoms van die moderne ateïsme is 'n redelik resente verskynsel. In die Bybel is daar nie juis sprake van ateïsme in die moderne sin van die woord nie - veel eerder van politeïsme. (Sommige dink dat selfs Israel aanvanklik politeïsties was vgl. Armstrong 1999:22, 23; Esterhuyse 2010:79. $)^{4}$

Die moderne ateïsme begin eers werklik in die agtiende eeu met die opkoms van die Aufklärung met sy rasionalisme (die menslike verstand is die hoogste maatstaf vir alles), opgevolg deur die positivisme (wetenskaplike bewysvoering as hoogste 'waarheid') (vgl. Armstrong 1999:338, 400-405).

2.Vergelyk Russell se boek Why I am not a Christian (2002 [1957]). By ' $n$ ander geleentheid, so word vertel, was Russell uitgenooi om 'n groep teoloë toe te spreek en toe iemand aan hom vra hoe hy tussen die groep teoloë voel, het hy opgemerk: 'Soos 'n leeu in 'n kuil vol Daniëls!'

3.Ek het in Julie 2012 'n omvattende artikel oor ateïsme voltooi wat hopelik in 2013 gepubliseer sal word.

4.Spangenberg (1998:32; 2009:85, 99-121) oordeel dat Israel se godsdiens eers politeïsties was, daarna henoteïsties en uiteindelik monoteïsties.
Hierdie tendens sou in die negentiende en twintigste eeue momentum opbou met die opkoms van 'n hele aantal teoretiese ateïste (vgl. Armstrong 1999:406-421; Durand 1976:102-118). Feuerbach (1804-1872) sien God as die wensprojeksie van die mens; Marx (1818-1883) beskou godsdiens as opium van die volk ('n stelling wat Lenin later sou wysig deur te beweer dat godsdiens opium vír die volk is); Nietzsche (1840-1900) verklaar triomfantelik dat die (metafisiese) God dood is; Freud (1856-1939) beskou geloof in God as 'n illusie - 'n projeksie van ons infantiele begeertes - wat volwasse mense moet aflê. Sartre (1905-1980) voer aan dat die erkenning van die bestaan van God 'n bedreiging inhou vir menslike vryheid en verantwoordelikheid, terwyl Camus (1913-1960), die groot held van die skrywer André P. Brink, in dieselfde rigting dink; die lewe is absurd en die enigste sinvolle reaksie teen die absurditeit is rebellie.

In die jongste tyd is dit veral die Britse wetenskaplike Richard Dawkins wat met sy invloedryke en wydgelese boek The God delusion (2007), die penne in beweging gebring het. Hierop het onder andere die McGraths met hulle boek The Dawkins delusion? (2007) en Lennox met sy twee boeke God's Undertaker (2009) en Gunning for God (2011), asook Nürnberger met sy boek Richard Dawkins' God delusion $(2010)^{5}$ gereageer. Laasgenoemde boek is egter vanuit 'n meer krities-teologiese benadering geskryf.

Dawkins voer aan dat, om in God te glo, nie net onwetenskaplik is nie, maar inderdaad ook gevaarlik. Die bestaan van God is nie wetenskaplik bewysbaar nie en geloof in Hom hoort eintlik by 'n primitiewe geloof tuis. Moderne mense moet hulle distansieer van 'n (Ou-Testamentiese) God wat samelewings laat verwoes en 'n Nuwe-Testamentiese God wat mense vir ewig laat verlore gaan.

Na die verskyning van Dawkins se boek, het die inwoners van London daarop gereageer met 'n groot advertensie op die bekende Londonse rooi busse met die woorde van Psalm 14 (Ps 53): 'Die dwaas sê in sy hart: daar is geen God nie.' Hierdie aanhaling is goed bedoel, maar het helaas nie die kol getref nie, want wat in Psalm 14 afgewys word, is praktiese ateïsme en nie teoretiese ateïsme waaroor Dawkins handel nie. Psalm 14 handel oor mense wat lééf asof God nie bestaan nie, al erken hulle tog dat Hy inderdaad bestaan. (Hier is 'n tipiese voorbeeld van hoe die Bybel foutief in die debat met teoretiese ateïste aangewend word.)

Die opkomende ateïsme is egter nie net tot die buiteland beperk nie, maar begin ook in Suid-Afrika al sterker op die voorgrond tree. Daar is reeds na die minder bekende boek van Pellencin verwys, maar meer bekend is die boek Geloof, bygeloof en ander wensdenkery (2008) van die voormalige joernalis George Claassen, subredakteur van die Burger en professor aan die Universiteit van Stellenbosch. Vir Claassen is enige geloof in God per definisie bygeloof. Die wetenskap werk met bewyse; die geloof, egter, met nie-bewysbare dinge en verval sodoende in bygeloof en wensdenkery. ${ }^{6}$

5.Twee boeiende boeke oor die ateïsme, geskryf deur voormalige ateïste, is McGrath The twighlight of atheism (2005) en Collins, The language of God (2007). Vergelyk ook Flew se There is a God (2008).

6.Vgl hier die standpunte van Feuerbach en Freud. 
'n Moderne tendens in die teologie is om nie ateïsties te dink nie, maar panenteïsties soos byvoorbeeld gebeur in die beweging wat as Nuwe Hervorming (NH) by ons bekend geword het sedert 2002 (vgl. Muller 2002). Binne hierdie denkraamwerk word daar nie aan God in persoonlike terme gedink nie (vgl. Durand 1976:50-62), maar dat God ín alles is en álles in God; dat God méér as alles is. Die eerste Waarde van die $\mathrm{NH}$ - hulle praat nie van 'n belydenis of dogma nie - lui soos volg: 'Ons aanvaar dat wanneer ons oor die goddelike praat, ons na die onbegryplike misterie van die lewe verwys wat ons onder andere in Jesus van Nasaret ken.'

Hierdie gedagtes tref ons onder andere aan by Hansie Wolmarans (Muller 2002:223), by die voormalige NG predikant Abel Pienaar in sy boek Saam op soek na God (2010:2, 105), sowel as by die voormalige Hervormde predikant Flip Schutte in Diaspora (2010:19). ${ }^{8}$

In hierdie verband moet opgemerk word dat alles afhang van die inhoud wat aan die begrip panenteïsme gegee word. Indien die vertolking daarvan neerkom op 'n opheffing van die onderskeid tussen Skepper en skepping, en daarmee saam op die uitfasering van die gebed as aanroeping van God, gaan dit teen die grein van die ganse bybelse boodskap in. Die vraag moet dan gestel word of panenteïsme (in sy radikale vorm) nie ' $n$ halfwegstasie is op pad na ateïsme nie - soos Bavinck iewers ten opsigte van deïsme opgemerk het (vgl. hier Potgieter 2002; Cooper 2007.)

Ateïsme sal, myns insiens, nooit daarin kan slaag om die diepste lewensvrae bevredigend en afdoende te beantwoord nie. Daarvoor is sy vooronderstellings, wat ek as naïewe rasionalisme en positivisme tipeer, te yl en onbevredigend. Die menslike verstand en die natuurwetenskap met al sy bewyse kan nie alle menslike vrae bevredigend beantwoord nie. Vrae soos:

- Wat is waarheid? (Hoe verwerf ons kennis?)

- Waar kom alles (uiteindelik) vandaan?

- Waar gaan alles (uiteindelik) heen?

- Wat is die sin van die lewe?

- Hoe onderskei ons tussen goed en kwaad?

Verwysings na die Big Bang, die Big Crunch en nihilisme is eenvoudig nie lewensbevredigende antwoorde nie. Dit vereis 'n yslike geloof om te aanvaar dat alles toevallig ontstaan het, so voortbestaan en uiteindelik in 'n groot Niks sal eindig.

Ons kan natuurlik nie met bogenoemde vrae op die sogenaamde Godsbewyse probeer terugval nie (ná Kant is dit nie meer moontlik nie), maar dit moet daarop gewys word dat hierdie vrae nie deur blote rasionaliteit en wetenskaplikheid bevredigend beantwoord kan word nie. Die sogenaamde postmodernisme het ons op hardhandige wyse herinner aan die voorlopigheid en onvoltooidheid van alle menslike kennis.

Wat die Godsleer betref, moet ons aan ten minste drie aspekte bly vashou (vgl. Klopper 2005; Vorster 2006):

7. Volgens' $n$ epos van Spangenberg aan my, gedateer 2 Novermber 2010.

8.Ook Julian Müller (2011:147-172) dink in hierdie rigting.
- Die eerste is God se uniekheid. God is Skepper en die skepping is skepping. Bavinck $(1978: 166,180)$ merk tereg op dat die Bybel deurgaans bedag is daarop om nie die Skepper en die skepping te vermeng nie. Vir die christelike geloof is die bestaan van God 'n geloofsvertrekpunt wat rus bring in 'n onrustige hart. Geloof in toeval as god en hoogste antwoord op menslike vrae, is vir die christelike geloof te skraal en onbevredigend.

- Die tweede is God se persoonlikheid wat impliseer dat ons as mense met Hom in 'n verhouding kan staan, en Hy met ons, dat ons tot Hom kan bid en onsself aan Hom kan oorgee. Meditasie is ' $n$ baie belangrike - en lank verwaarloosde - onderdeel van die christelike lewe, maar dit mag nooit die persoonlike gebed tot God vervang nie.

- Die derde is God se goedheid met die implikasie van sy nabyheid. Dit is waar dat God ook 'n God is wat oordeel tussen goed en kwaad, maar dit is óók waar dat die goedheid van God 'n deurlopende tema in die ganse Ou Testament is (Eks 34:6; Ps 86:15; Ps 103:8; Ps 145:8; Jona 4:2; Joël 2:13; Neh 9:7). God is 'n God wat mense se trane raaksien, byvoorbeeld dié van Hagar (Gen 16:13), van Dawid (Ps 56:9), van Hiskia (Jer 38:3) en van die Nineviete (Jona 3). Die Nuwe Testament eindig as 't ware met die asemrowende uitspraak 'God is liefde' (1 Joh 4:8). Hy het die (sondige) wêreld só liefgehad dat Hy sy Seun gestuur het as 'n versoening vir ons sondes (Joh 3:16, 1 Joh 2:2). Inderdaad, 'God is lig, en daar is geen duisternis in Hom nie' (1 Joh 1:5).

\section{Die diskoers oor Jesus}

'Wie is Jesus?', is die groot vraag wat deur alle eeue gevra en uiteenlopend beantwoord word. ${ }^{9}$ Die dogmageskiedenis word deur twee, nee, drie antwoorde op hierdie vraag oorheers: die eerste is dat Jesus waarlik mens was, 'n goeie en voorbeeldige mens met buitengewone profetiese gawes, maar niks meer nie (ebionitisme). Die tweede antwoord is dat Jesus waarlik God is, maar nie waarlik mens nie (dosetisme). Die derde benadering vind ons in die klassieke antwoord van Nicea: waarlik mens én God in een Persoon - onafskeidbaar en terselfdertyd onvermengbaar.

Deur alle eeue was daar stromings wat veral moeite gehad het met die Godheid van Jesus. In die Vroeë Kerk was daar Arius van Alexandrië (vierde eeu), Hy was wel nog bereid om van Jesus se 'goddelikheid' te praat (Armstrong 1999:130). Tydens die Aufklärung, met die opkoms van rasionalisme, het die denkwyses oor Jesus nuwe wendings geneem. Reimarus (1694-1768) was hierin die voorloper. Jesus was, volgens hom, 'n gewone mens wie se politieke aspirasies misluk het. Die historiese Jesus en dít wat die kerk later van Hom gemaak het, is eintlik twee verskillende figure. Hierop volg D.F. Strauss (1808-1874) met sy mitiese Jesusbeeld. Dit is geen wonder dat Strauss uiteindelik sy rug op die christelike geloof gedraai en 'n ateïs geword het nie. (Op grond van die invloed van die liberale teologie van Strauss, het Karl Marx

9.Vergelyk in hierdie verband die verskillende Christologieë en Jesulogieë wat (net) in Suid-Afrika verskyn het: Van Aarde (2001); König (2001), Du Plessis (2005), in Suid-Afrika verskyn het: Van Aarde (2001); König (2001), Du Plessis (2005),
Nolan (2006), Wessels (2006), Craffert (2008), Schutte (2008), Spangenberg (2009), Joubert (2009), Van der Watt, Joubert, Tolmie \& De Villiers (2010). 
'n ateïs geword - dieselfde Marx wat in sy katkisasiedae as jong Lutheraan 'n opstel geskryf het oor 'Die vereniging van die gelowige met Christus'.)

In die twintigste eeu was dit die groot Duitse NuweTestamentikus, Bultmann (1884-1976), wat die ontmitologiserings proses die verste deurgevoer het. Hy onderskei duidelik tussen die historiese Jesus en die verkondigde Christus. Die opstanding van Christus is deel van die mitologiese wêreldbeeld en mag nie as historiese gebeurtenis verstaan word nie. Wat belangrik is, is nie die vraag of Jesus in die tuin van Josef opgestaan het nie, maar of Hy - sy boodskap altans - in die mens se hárt opstaan en leef. ${ }^{10}$

In 1985 ontstaan daar in Amerika 'n beweging van hiperkritiese teoloë, naamlik die Jesus Seminaar. Hulle het veral baie waarde geheg aan die nuut ontdekte Evangelie van Tomas in Nag Hammadi (1945) in Egipte. In wese is die beskouing van die Jesus Seminaar 'n voortsetting van die denke van Bultmann, met die gevolg dat die liggaamlike opstanding van Jesus geëlimineer word.

Ons het reeds verwys na die ontstaan van die Nuwe Hervorming in Suid-Afrika sedert 2002. Hierdie denkskool vind ook sterk aansluiting by die Christologie, of eerder Jesulogie, van Bultmann - en dit in 'n tyd dat daar weinig of geen navolger van Bultmann in Duitsland meer is nie. ${ }^{11}$

Dit alles impliseer dat die klassieke Christologie, waar die uniekheid van die persoon en werk van Jesus bely word, gereduseer word tot Jesus-as-voorbeeldige-mens. Die jongste voorbeeld hiervan is te vinde in die boek Jesus van Nasaret (2009) van Sakkie Spangenberg. Hy argumenteer dat daar duidelik tussen drie Jesusbeskouings onderskei moet word, naamlik eerstens, die historiese Jesus (soos hy op aarde geleef en gewerk het); tweedens, die vertelde Jesus (soos die Bybelskrywers hom weergegee het); en derdens, die dogmatiese Jesus (wat die kerk vele eeue later bely het). Waaroor dit eintlik gaan, is die historiese Jesus en daardie Jesus ontdek ons slegs deur 'wetenskaplike navorsing'. Die Bybel is 'n boek wat slegs reg verstaan kan word deur die teologie as wetenskap - nié deur die kerk (Rome) of deur 'n individu (Reformasie) nie. Spangenberg (2009:362) eindig sy boek deur daarop te wys dat Jesus slegs 'n Joodse profeet en wysheidsleermeester was en dat hy foutiewelik in die vierde en vyfde eeu deur die kerk tot ' $\mathrm{n}$ god omvorm is. Binne hierdie denkraamwerk is daar nie plek vir die kruisgebeure as soendood en oorwinning oor die sonde asook vir die opstanding as oorwinning oor die dood nie.

Een van die Waardes van die Nuwe Hervorming lui dat 'n mens die onbegryplike misterie van die lewe (die goddelike) 'onder andere' in Jesus van Nasaret (kan) leer ken. Daar mag dus ook ander wees soos Boeddha, Gandhi, ensovoorts. ${ }^{12}$

10.Vergelyk in hierdie verband die aansluiting van Schutte $(2008 ; 2010: 81-84,135,146$ 166) by die denke van Bultmann: Jesus moet in jou hárt opstaan.

11.In Suid-Afrika is daar wel teoloë wat by die benadering van Bultmann aansluit, byvoorbeeld die Hervormde teoloë A.G. van Aarde, G.M.M. Pelser, G. Malan.

12.In'n persoonlike epos aan my in 2010 het Spangenberg dit toegegee. Ook Abel Pienaa (2010:3) is van mening dat Jesus vir hom 'n figuur soos Gandhi en Boeddha is.
Myns insiens moet ons, hierteenoor, volgens die Skrifgetuienis en die regula fidei van die kerk van alle eeue eerstens vashou aan die uniekheid van die persoon en werk van Jesus Christus. Indien ons dít laat vaar, kan ons nie meer met 'n goeie gewete die Bybel as normatiewe teks aanvaar nie, maar dan word die Bybel een van vele boeke wat inspireer ('n 'boek onder andere', soos die Waardes van die Nuwe Hervorming lui). Dan is dit nie meer vanselfsprekend dat die Bybel meer waarde het as die Koran van die Moslems, Cervantes se Don Quixote, Heidegger se Sein und Zeit of Tolkien se The Lord of the Rings nie.

Tweedens moet ons as christene ook onwrikbaar vashou aan die belydenis van die liggaamlike opstanding van Jesus. Indien dít wegval, stort die totale boodskap van die Christelike geloof in duie. As motivering vir hierdie benadering, kan op die volgende aspekte gewys word: ${ }^{13}$

- In die heel vroegste evangelieverkondiging in die boek Handelinge 1-19 funksioneer die (liggaamlike) opstanding van Jesus as essensie van die evangelie. Eers vanaf Handeling 20 kom die kruis as deel van die evangelie ter sprake.

- Soms word die hele evangelie saamgevat met 'n verwysing na die opstanding (Rom 10:9; 2 Tim 2:8).

- Die vroegste Nuwe-Testamentiese geskrif, 1 Tessalonisense (50 n.C), verwys eksplisiet na die opstanding (1 Tess 1:9-10; 4:13-18).

- Al vier die evangeliste, waaronder 'n mediese dokter (Lukas), verwys eksplisiet na die opstanding, al is dit met verskeie variasies. Selfs Paulus het beweer dat hy die opgestane Jesus ontmoet het.

- Al vier die evangeliste, asook Paulus, maak melding van die verskyning van Jesus na sy opstanding aan lewende persone.

- Die boodskap van die opstanding van Jesus word in 'n sosio-kulturele (Hellenistiese) konteks verkondig waarin die opstanding skerp bevraagteken is. Paulus se boodskap van die opstanding bring hom in direkte konflik met die idealisme van Plato en die materialisme van Epicurus en Stoa (Hand 17).

- Paulus bring die opwekking van die Here (Jesus) ook ter sprake as demonstrasie van die Godheid van die Skeppergod (1 Kor 5:14; vgl. Rom 8:11).

- 'n Blote metaforiese verstaan van die opstanding word in die Nuwe Testament self afgewys (2 Tim 2:17-18) (Himeneus en Filetus).

- In die hele Nuwe Testament word die opgestane Jesus deurlopend as lewende Here beskryf en nie as dooie persoon aan wie se lewe en optrede gelowiges bloot dankbaar herinner moet word nie. Sou die vroeë christene hulle lewe vir 'n dooie Jesus afgelê het -, iemand wat slegs 'n mooi voorbeeld gestel het? Aan wat anders (as

13.Vergelyk in hierdie verband die gesprekke wat Gaum (2004) gevoer het asook die omvattende studie van Licona (2010) oor die opstanding. In sy twee boeke skryf Julian Müller (2006, 2011) Laco (20) or die opstanding. In sy twee boeke skryf Julian Müller (2006, 2011) vaag en dubbelsinnig oor die opstanding van Jesus. Vergelyk hier die kritiese reaksie van König (2009:236-253) op Müller se standpunt asook die pspraakwekkende boek van Ferdie Mulder (2011) - uiteraard vanuit ' $n$ bepaald ubjektiewe perspektief. Vir die optrede van Flip Schutte het ek besondere respek, aangesien hy na sy radikale herverstaan van die evangelie, uit die (Hervormde) kerk bedank het en 'n ander werk gaan doen het; hy kon eenvoudig nie meer met Kerstyd en Lydenstyd 'eerlik preek' nie (Jackson 2008:17). 
die opgestane Jesus) is die snelle groei van die vroeë kerk te danke?

- As Christus nie waarlik opgestaan het nie, hoe kon die vroeë christene Hom as lewende Here aanbid het?

- Watter sinvolle betekenis moet daar aan die leë graf gegee word indien Jesus nie opgestaan het nie?

- Die oorgang van die Sabbat as dag van erediens na Sondag as 'Dag van die Here' en ontmoeting met die Here wat in die Vroeë Kerk plaasgevind het, kan volledig toegeskryf word aan die feit dat Christus op Sondag uit die dood opgestaan het.

- Op watter sinvolle wyse kan Westerse teoloë met OostersOrtodokse (en Afrika-) teoloë, wat nie die rasionalisme van die Aufklärung meegemaak het nie en vir wie die opstanding 'n essensiële deel van die evangelie uitmaak, kommunikeer indien hulle (die Westerse teoloë) die liggaamlike opstanding prysgee?

Ons moet wel verstaan dat die opstanding of opwekking van Jesus 'n groter gebeurtenis was as dié van Lasarus wat later weer gesterf het. Jesus het deur die dood heen gegaan en het as oorwinnaar en lewende Here anderkant die graf verskyn.

Teoloë en predikers het in hierdie verband ' $n$ belangrike taak. Omdat die Nuwe Hervormers ywerige briefskrywers in ons dagblaaie is, is dit belangrik dat hierdie tema(s) tydens huisbesoek, kategese en Woordverkondiging indringend, sinvol en op pastorale wyse aan die orde gestel sal word. Dit impliseer dat hulle wyd moet lees en breed moet oriënteer. Evangelieverkondigers kan nie leiding gee indien hulle nie weet wat in die teologiese wêreld in debat is nie.

\section{Die diskoers oor die mens (en die menslike samelewing) ${ }^{14}$}

Een van die tipiese kenmerke van die twintigste eeu is die besondere klem wat daar op die mens - en sy regte - geplaas word, dit wil sê op humaniteit en selfs humanisme. Dit is bekend dat die humanisme 'n lang geskiedenis het, van die Renaissance (veertiende tot sewentiende eeue), oor die Aufklärung (agtiende eeu) tot in die moderne en sogenaamde postmoderne tyd. Hierdie lewensfilosofie vra aandag, nié vir die hemelse nie, maar vir die aardse dinge; vir die mens, as individu, maar ook (al meer) vir die mens binne sisteme, strukture en samelewingsverbande.

Die vraag na die mens is, teologies gesien, natuurlik ' $n$ uiters belangrike vraag. Te lank is daar in die teologie gedink dat die godheid van God beklemtoon moet word ten koste van die menslikheid van die mens. As die medemenslikheid van humaniste byvoorbeeld dié van christene oortref, het christene die christelike boodskap grondig misverstaan.

In hierdie verband kan gedink word aan vrae uit die individuele etiek, maar ook aan vrae uit die sosiale etiek. Eersgenoemde gee aandag aan vraagstukke uit onder andere die mediese etiek, soos byvoorbeeld kloning en stamselnavorsing.

14.In plaas van om die diskoers oor die 'mens' te bespreek, sou hier ook sinvol oor die diskoers oor die 'kerk' gehandel kon word, naamlik vrae oor die verskeurdheid van die kerk(e), onenigheid in die kerke(e), diversiteit in die kerk(e), die eenheid van die kerk en die integriteit van die kerk.
In hierdie artikel word veral aandag gegee aan vrae uit die sosiale etiek wat ons menswees ten diepste raak. Die eerste aspek handel oor die politieke etiek en die tweede oor die ekonomiese etiek.

Die begrip politieke etiek mag dalk vreemd voordoen, maar ons moenie dink dat so 'n onderwerp nie in die teologie tuishoort en baie ver verwyder is van die Godsleer en Christologie nie. Veral nie in die reformatoriese tradisie waar nog altyd aanvaar is dat die lig van die evangelie van die koninkryk op alle lewensterreine moet val nie. Dit is daarom nie 'n verrassing dat Calvyn sy Institusie (1559) afsluit met 'n hoofstuk wat oor die burgerlike regering handel nie (Inst., 4.20).

In hierdie verband verwys Calvyn na die verskillende soorte regeringsvorms soos tirannie, monargie, aristokrasie, oligargie en demokrasie. Hy merk op dat die beste vorm dalk 'n aristokrasie of demokrasie kan wees (Inst, 4.20.8). Die belangrikste is egter nie wíe regeer nie, maar hóé regeer word. Dit is opvallend hoeveel klem Calvyn hier op die beskerming van burgerlike vryhede (Inst., 4.20.8), asook op geregtigheid plaas (Inst., 4.20.9). 'n Mens sou kon sê dat 'n goeie regering vir Calvyn deur die handhawing van vryheid en geregtigheid in die samelewing gekenmerk word.

Dit is algemeen bekend dat ons in Suid-Afrika sedert 1994 'n demokratiese regeringsvorm gekry het en sedert 1996 'n Grondwet wat wêreldwyd aangeprys word. Daarin word basiese regte soos menswaardigheid, vryheid en gelykheid verskans (vgl. veral Vorster 2004; N. Vorster, 2007). Wat almal egter nie besef nie, is dat daar in die politieke etiek verdere nadenke plaasgevind het waarin onderskei word tussen twee soorte demokrasieë, naamlik 'n liberale demokrasie wat die individu as vertrekpunt neem, en 'n plurale demokrasie wat rekening hou met taal- en kultuurgroepe in 'n samelewing. 'n Liberale demokrasie werk goed in 'n homogene samelewing, maar 'n plurale demokrasie weer beter in ' $n$ plurale samelewing.

Ons dilemma in Suid-Afika is tans dat ons met 'n liberale demokrasie in 'n plurale samelewing werk. Die Grondwet (Republiek van Suid-Afrika 1996: art. 2.31) verwys wel na die reg van taal- en kultuurorganisasies, maar dit is onduidelik wat die politieke relevansie van hierdie organisasies is in 'n bedeling waar die individu as vertrekpunt geneem word. Die Grondwet erken met ander woorde baie duidelik individuele regte, maar is vaag ook die reikwydte van groepsregte.

Hier lê 'n groot braakland, nie net vir politici en politikoloë nie, maar ook vir teoloë om verder na te vors of 'n plurale model nie groter vryheid, regverdigheid en harmonie in ons samelewing sal vestig nie en, indien wel, hoe dit tot praktiese uitvoering gebring kan word (vgl. hier N. Vorster 2007; De Kruijff 1994)..$^{15}$

15.Die filosoof Degenaar (1976:92-109; 1980:109-141) is' $n$ voorstander van die plurale model. 'Teenoor die volksnasionalisme, wat politiek op apartheid tussen volke baseer, en liberalisme, wat politiek bedryf op die beginsel van een-man-een-stem, respekteer pluralisme groepsverskille en kultuurverskeidenheid sonder om dit te respekteer pluralisme groepsverskille en kultuurverskeidenheid sonder om dit te
verabsoluteer' (Degenaar 1980:138). Hierdie woorde van Degenaar is lank voor verabsoluteer' (Degen
1994 en 1996 geskryf. 
Die tweede aspek gaan oor ekonomiese etiek, naamlik oor die vraag na die waardevolste ekonomiese sisteem: kapitalisme of sosialisme (respektiewelik kommunisme).

Dit is algemene kennis dat sosialisme as ekonomiese sisteem, breedvoerig deur Marx uiteengesit en verdedig in Das Kapital (1867) in 1989 met die val van die Berlynse muur, soos 'n kaartehuis inmekaar gestort het. Sommige Afrikastate het daarmee probeer eksperimenteer, maar meestal tot groot nadeel vir die hele samelewing (vgl. DR Kongo). In enkele ander lande, soos Kuba en China, is daar nog (die laaste?) stuiptrekkings daarvan te bespeur.

Die vraag is nou: Impliseer die val van sosialisme dat kapitalisme dus die beste ekonomiese sisteem vir die wêreldsamelewing is? Dit is bekend dat Max Weber die Calvinisme, met sy prestasiemoraal en dikwelse werkwoede, daarvan beskuldig het dat dit, weliswaar onregstreeks, verantwoordelik was vir 'n ontaarde kapitalisme - ten onregte, maar dis weer 'n onderwerp op sy eie (vgl. Van Wyk 1984:23-24).

Op die vraag of kapitalisme die mees verantwoorde ekonomiese stelsel is, moet, myns insiens, negatief geantwoord word, maar hierdie uitspraak moet ook verder krities ondersoek word. Sosialisme het in 1989 tot ' $n$ val gekom en almal het toe gedink dat kapitalisme ongestoord sou voortduur. Dit was egter 'n vergissing, want in 2008 het die Westerse kapitalisme vanweë die Amerikaanse ekonomiese krisis 'n skok ontvang waarvan die sisteem nou nog nie herstel het nie en tans nog groot onbestendigheid vertoon (vgl. hier ook die ekonomiese krisisse wat onder andere Griekeland, Ierland en Italië in die Europese Unie veroorsaak het).

Daar is wêreldwyd al hoe meer 'n tendens wég van sosialisme, maar ook wég van kapitalisme na 'n middeweg, na 'n meer geleide vryemarksisteem, ook bekend as sosiale demokrasie (teenoor demokratiese sosialisme).

Ook hier lê 'n groot veld braak vir die teologie en die sosiale etiek, juis vir 'n land soos Suid-Afrika met sy groot uiterstes van rykdom en armoede - wat trouens 'n wêreldwye verskynsel is. Dit bly 'n voortdurende uitdaging om te soek na 'n ekonomiese stelsel waarin daar meer vryheid is as in die sosialisme, maar ook meer regverdigheid as in die kapitalisme. Sodanige navorsing impliseer ' $n$ ontginning van die bybelse perspektiewe op 'n vrye en regverdige samelewing, navorsing waarin die Christologie in al sy volheid deeglik verreken behoort te word. ${ }^{16}$

\section{Die diskoers oor die aarde}

Hierdie artikel het 'hoog' - met God - begin en dit is gepas om 'laag' - met die aarde - te eindig. Die aarde is immers die woonplek van die mens en die vraag ontstaan hoe hierdie menslike woning daar uitsien. Het die mens met sy tegnologiese kundigheid die aarde in 'n paradys omskep of in 'n rowerspelonk verander? Besef die mens dat hy rentmeester op aarde is - 'die aarde en alles wat daarop is, behoort aan die Here' (Ps 24:1) - of het die mens met sy prestasiewoede, magsug en genotsug die aarde en natuurlike hulpbronne uitgeput en verniel?

Die Here het die aarde aan die mens geskenk om dit te bewoon en te bewerk, te vul en op te pas. Die vraag wat onmiddellik hier ontstaan, is of die aarde met sy 7 miljard bewoners nie reeds gevul is nie. Sommige meen die aarde is reeds 'oorvol'. Hierdie toedrag van sake roep nuwe besinning op oor byvoorbeeld gesinsbeplanning en huweliksetiek. Hoe sien 'n verantwoorde huweliksetiek daar uit in die konteks van 'n oorbevolkte wêreld? Iets waarvoor die Britse ekonomis en teoloog Malthus reeds in 1798 (en 1803) aandag gevra het en toe erg verkwalik is (vgl. Van Wyk 1986:162-170).

'n Oorvol aarde impliseer natuurlik dat daar oormatige en toenemende druk op die natuurlike hulpbronne soos grond, water en minerale geplaas word. Ekoloë voorspel dat, indien daar nie iets drasties verander nie, die wêreld teen 2050 (dan met 9 miljard mense) op 'n ekologiese ramp afstuur wat die wêreldsamelewing kan laat inplof. Die mensdom sien hierdie naderende ramp nie raak nie, want elkeen jaag met oogklappe in dolle vaart deur sy week-, maand- en jaarprogram. Dit is asof die mensdom in 'n roeibootjie sit en die lekgate toestop en nie opmerk dat die damwal laer af besig is om te breek nie. Die ekologiese krisis is 'n sluipende monster wat ons stadig maar seker bekruip en gaan oorval.

Hoe lyk die ekologiese prentjie (vgl. Van Wyk 2009:159-160)? Ekoloë vertel van aardverwarming wat die poolgletsers laat smelt, losbreek en laat wegdryf; van die gat in die osoonlaag wat al groter word en al meer ultraviolet sonstrale deurlaat; van $80 \%$ van die wêreld se inheemse woude (ons suurstoffabrieke) wat reeds vernietig is; van verwoestyning wat toeneem; van die biodiversiteit wat vinnig afneem, ensovoorts.

Wat Suid-Afrika betref: ons is een van die wêreld se tien grootste besoedelaars en genereer jaarliks 560 miljoen ton afval; teen 2025 staar ons 'n ernstige waterkrisis in die gesig indien ons waterbronne nie oordeelkundig bestuur word nie; talle van ons riviere is oorvloei met rioolafval en die beheer daaroor is baie swak; die ondergrondse suurwatervlakke van ou myne in die Witwatersrandgebied is besig om te styg en dit word ' $n$ al hoe groter bedreiging vir die stad Johannesburg, terwyl daar nog geen omvattende plan is om die probleem op te los nie, ensovoorts.

Dit is duidelik dat die wêreldsamelewing, Suid-Afrika ingesluit, nie langer met die ongebreidelde omgewingsbesoedeling en -vernietiging kan voortgaan nie. Ons wil tog nie aan ons nageslag ' $n$ vernielde aarde en verwoeste wêreld nalaat nie? Dit geld te meer vir ons as christene; ons wat juis daarvan beskuldig word (deur Lyn White) dat ons arbeidsetiek met sy ingeboude element van werkwoede 'n mede-oorsaak is van die moderne ekologiese krisis. 
Die wêreldsamelewing sit egter met 'n byna onoplosbare dilemma: enersyds moet ons die omgewing bewaar, maar andersyds moet daar ontwikkeling, werkskepping en vooruitgang plaasvind. ${ }^{17}$ Armoede en werkloosheid moet tog bestry en opgeruim word. Dit laat die morele vraag ontstaan: Hoe kan 'n sinvolle balans tussen ontwikkeling enersyds, en bewaring andersyds, gevind word? 'n Balans dus tussen ekonomie en ekologie. Hier lê 'n groot studieveld braak vir 'n ondersoek vanuit die perspektief van kontekstuele christelike etiek (vgl. Manenschijn 1988; Retief 2002; Buitendag 1985). ${ }^{18}$

Ondertussen is die bewaring van die omgewing en die voorkoming van besoedeling asook die aankweek van 'n ekologiese sensitiwiteit 'n noodsaaklike opdrag aan elke christen sowel as aan die christelike kerk.

Dit is baie belangrik dat juis in die christelike kerk groot erns gemaak moet word met omgewingsbewaring en dat predikante tydens huisbesoek, kategese-onderrig en in die prediking hierdie tema ter sprake sal bring. Hoeveel sinodebesluite is al oor hierdie belangrike saak geneem? As sinodes besluite kon neem oor dans en dobbel en kaartspel, behoort hulle dan nie ook besluite te neem oor die bewaring van die omgewing - God se skepping - nie ? $^{19}$

\section{Enkele riglyne vir goeie teologie}

Hierdie besinning word afgesluit met wat, volgens die skrywer, as enkele belangrike kenmerke van 'goeie teologie' beskryf kan word.

Drie kenmerke van wat goeie teologie nié behoort te wees nie word eerstens uitgelig:

- Dit moet nie fundamentalisties wees nie (vgl. Vorster, 2008). Natuurlik bestaan daar so iets soos fundamentele waarhede, selfs vir elke wetenskap, maar teologiese fundamentalisme neem te dikwels 'n kortpad en reken dat daar met 'n paar los Bybeltekste, meestal totaal buite konteks aangehaal, 'n debatspunt besleg kan word. Die fundamentaliste bedoel dit goed, maar met hulle onverantwoordelike Skrifhantering doen hulle dikwels meer skade as goed aan die boodskap van die Bybel.

- Myns insiens sal die Charismatiese teologie ook nie ons probleme na wense kan hanteer nie. Weereens, alle goeie teologie is charismaties van aard, in die sin van 'besiel deur die Heilige Gees', maar die charismatiese teologie van die Charismatiese Beweging is dikwels te oppervlakkig en te fundamentalisties om die moderne teologiese vrae sinvol te beantwoord.

17.' $n$ Tipiese voorbeeld van hierdie dilemma was in September 2012 in Suid-Afrika ter sprake: Die Shell-maatskappy het beplan om skaliegas in die Karoo deu middel van hidrobreking te ontgin. Enersyds sou die energietekort verlig en baie werkgeleenthede geskep word en andersyds sou die omgewing besoedel en die onderaardse water grondig versteur word.

18.In hierdie verband kan met dank verwys word na die TV-program Groen wat deur Dave Pepler en sy span aangebied word; ook na die gereelde koerantartikels van Elise Tempelhoff oor die omgewing; en na die radiopraatjies van prof. Kobus van der Walt van die Noordwes-Universiteit op Saterdagoggende.

19.In 2012 het die Algemene Sinode (GKSA 2012 art. 23) ' $n$ baie belangrike besluit oor die ekologiese krisis geneem. Die skrywer en prof. Kobus van der Walt van die NoordwesUniversiteit was verantwoordelik vir die opstel van die konsepbeskrywingspunt (Die Acta 2012 het by die skryf van die artikel nog nie verskyn nie.)
- Volgens my oordeel sal die hiperkritiese teologie - wat ons as kritisisme kan tipeer - ons ook nie veel baat nie. Hierdie teologie 'maak nie aanspraak op ewige waarhede nie' (NH), 'n uitspraak wat natuurlik 'n contradictio in terminis is - dit word tog immers as 'waarheidsuitspraak' voorgehou. 'n Mens kan nie die fondament waarop die teologie gebou is, byvoorbeeld die Christologie ondermyn en dan nog hoop dat dit staande sal bly nie. Sonder twyfel is goeie teologie rasioneel verantwoorde teologie, maar dit gee nie aan rasionalisme of 'wetenskaplike navorsing' die laaste woord nie.

Wat is die kenmerke van goeie teologie dan wél?

- Goeie teologie is teosentries van aard; dit gee aan God die eer, neem Hom as vertrek- en eindpunt van die teologiese wetenskap - en van die lewe. Dit gaan in goeie teologie oor nadenke oor die Vader en die skepping, die Seun en ons verlossing en die Heilige Gees en ons vernuwing (vgl. HK 8:24).

- Goeie teologie is Skriftuurlik verantwoorde teologie. Dit neem as vertrekpunt die Bybel as normatiewe teks en nie bloot as menslike gedagtes oor God nie (NH), maar inderdaad ook Goddelike gedagtes oor die mens en wêreld. Dan moet ons egter onmiddellik iets baie belangrik byvoeg: die Bybel moet rég, dit wil sê Christologies, verstaan word (Luk 24:44; Heb 1:1-2). Wie die Bybel en enige teologiese vraagstuk buite Christus om probeer verstaan, sal dit verkeerd verstaan omdat ons in Christus met God se laaste en hoogste openbaring te doen het. Juis dít was een van die groot leemtes van die apartheidsteologie: Christus het nie daarin 'n sentrale plek ingeneem nie. Natuurlik kan die kerklike ekumene, sowel as kerklike belydenisskrifte ' $n$ belangrike rol in hierdie verband speel, soos wat die Gereformeerde Ekumeniese Sinode/Raad inderdaad tydens die apartheidsdebat gedoen het, want Paulus skryf dat ons eers die grootte van die liefde van Christus 'saam met al die heiliges' moet ontdek (Ef 3:18).

- Goeie teologie is koninkryksentriese teologie. Dit maak erns daarmee dat die sentrale tema van die hele Bybel, en in besonder dié van Jesus Christus, die koninkryk van God is, dit wil sê die heilsame heerskappy van God oor alles wat met die koms van Jesus Christus en die Heilige Gees sigbare gestalte op aarde aangeneem het. Daarom stel goeie teologie in alles belang wat op die aarde gebeur - in die welsyn van die mens, die goed en kwaad van menslike sisteme en strukture, maar ook in die omgewing en die aarde. Alles word vanuit die perspektief van die komende koninkryk van God beskou en benader. Hier is geen duimbreedte uitgesluit nie. (Dit is egter ' $n$ ander benadering as Kuyper se perspektief wat die hele samelewing wou verchristelik.)

- Goeie teologie is ook kerklike teologie. Goeie teologie fokus ook op die kerk, die opbou en groei van die kerk en die opbou van die geloofslewe van gelowiges. Juis daarom is goeie teologiese opleiding van toekomstige predikante aan goeie teologiese skole so belangrik. Jong dominees moet as goed toegeruste dienaars die evangelie van God se genade in Christus wyd en syd verkondig. Daarom is 'n goeie verhouding tussen kerk en teologie (respektiewelik teologiese skool) altyd belangrik. 
- Goeie teologie is ook kontekstuele teologie. As ek terugkyk op my eie lewe en hoe ons gereformeerde teologie in SuidAfrika in die verlede beoefen het, dan dink ek dat juis hierdie aspek een van ons grootste leemtes was, naamlik 'n gebrek aan verantwoordelike kontekstuele teologie. Ons het wel die prinsipes uitgespel, maar nagelaat om konkreet aan te toon hoe dit in die praktyk van die Suid-Afrikaanse samelewing met sy rasseproblematiek, toegepas moes word. Teologie word nie in 'n vakuum beoefen nie, maar binne 'n bepaalde sosiale, kulturele, ekonomiese en politieke konteks. Vrae binne daardie konteks moet hanteer word, en nie vrae wat honderd jaar gelede belangrik was nie. Dit geld natuurlik vandag net soveel vir die teologie binne die nuwe Suid-Afrikaanse konteks met sy vraagstukke van armoede, werkloosheid, misdaad, moord, korrupsie, omkopery, nepotisme, vigs, swak dienslewering, ensovoorts.

- Goeie teologie is uiteindelik ook wetenskaplik verantwoorde teologie. Dit is nie waar dat hoe meer Skriftuurlik teologie is, hoe minder rasioneel en wetenskaplik dit word nie. Goeie teologie ontken nie rasionaliteit nie (sacrificium intellectus), maar wel die feit dat rasionalisme die menslike verstand as die hoogste maatstaf van alles beskou. Goeie teologie waak teen 'sweeping statements', veralgemenings, foutiewe konklusies en in die algemeen teen goedkoop argumente. Dit alles impliseer dat dominees nooit mag ophou studeer nie, al is dit net vir algemene toerusting. ' $n$ Nederlandse predikant het by geleentheid opgemerk dat hoe meer teologiese en ander boeke hy lees, hoe makliker word sy preekvoorbereiding. Daar is ook 'n Nederlandse spreuk wat lui (vertaal): 'Wie nie studeer nie, is nie bekeer nie.' Teologiese studente moet besef dat die ses of sewe jaar teologiese opleiding eintlik maar 'n inleiding tot die teologie is en dat hulle eintlike studie eers begin nádat hulle as predikant bevestig is.

\section{Uitleiding}

In die lig van bostaande is dit duidelik dat die tyd vir debat oor middelmatige sake uitgeloop het. 'n Kerk en teologie wat nog daarmee besig is, raak irrelevant. Ons moet op daardie dinge fokus wat werklik saak maak; op daardie dinge wat van wesenlike belang vir die koms van die koninkryk van God is.

Ons het oor die relevansie van God en Jesus, sowel as oor die betekenis van die mens, die menslike samelewing en die aarde gehandel. Die christelike lewe as koninkrykslewe word binne hierdie wye raamwerk voltrek: in verbondenheid met God, in navolging van Jesus Christus, vernuwe deur die Gees, diensbaar aan die koninkryk en in die lig van die Skrif. Goeie teologie behoort hieraan diensbaar te wees.

\section{Erkenning \\ Mededingende belange}

Die outeur verklaar dat hy geen finansiële of persoonlike verbintenis het met enige party wat hom nadelig kon beïnvloed in die skryf van hierdie artikel nie.

\section{Literatuurverwysings}

Armstrong, K. 1999, A history of God: From Abraham to the Present: the 4000-year Quest for God, Vintage Books, London.

Bavinck, H., 1978, Our reasonable faith: A survey of Christian doctrine, transl. H. Zylstra, Baker, Grand Rapids.

Buitendach, J., 1985, 'Skepping en ekologie: 'n Sistematiese ondersoek na die teologiese verstaan van die werklikheid', DD-verhandeling, Universiteit van Pretoria.

Calvyn, J. [1542], Kategismus, vert. H.W. Simpson, Potchefstroom Teologiese Publikasies, Potchefstroom.

Calvyn, J. [1559], 1984, 1986, 1988, 1991, Institusie van die Christelike Godsdiens. Dele 1-4, CJBF, Potchefstroom.

Claassen, G., 2008, Geloof, bygeloof en ander wensdenkery, Protea Boekhuis, Pretoria.

Collins, F., 2007, The language of God. A scientist presents evidence for belief, Pocket Books, London.

Cooper, J.W., 2007, Panentheism. The other god of the philosophers. From Plato to the Present, Apollos/InterVarsity Press, Nottingham.

Craffert, P.C., 2008, The life of a Galilean shaman: Jesus of Nazareth in anthropologicalhistorical perspective, Cascade, Eugene.

Dawkins, R., 2007, The God delusion, Black Swan, London.

Degenaar, J., 1976, Moraliteit en politiek, Tafelberg, Kaapstad.

Degenaar, J., 1980, Voortbestaan in geregtigheid. Opstelle oor die politieke rol van die Afrikaner, Tafelberg, Kaapstad.

De Gruchy, J.W., 1991, Liberating reformed theology. A South African contribution to an ecumenical debate, Eerdmans, Grand Rapids.

De Gruchy, J.W., 2011, 'Transforming traditons. Doing theology in South Africa today', Journal of Tehology for Southern Africa 139, 7-17.

De Kruijf, G.G., 1994, Waakzaam en nuchter. Over christelijke ethiek in een democratie, Ten Have, Baarn

Du Plessis, I., 2005, Jesus: die keuse: eerlike geloofsvrae oor die Jesusgesprek, Lux Verbi. BM, Wellington.

Durand, J.J.F., 1976, Die lewende God, NG Kerkboekhandel, Pretoria.

Esterhuyse, W., 2010, Die God van Genesis: drama in die amfiteater van die Oneindige, Christelike Media Publikasies, Durbanville.

Flew, A. 2008, There is a God: How the world's most notorius atheist changed his mind, Harper Collins, New York. (With R.A. Varghese.)

Gaum, F. (red.), 2004, 20 Gesprekke oor die opstanding van Jesus uit die dood, Ex Animo, Kaapstad.

GKSA, 2012, Notule van die Algemene Sinode van die Gereformeerde Kerke in SuidAfrika, Potchefstroom.

Jackson, N., 2008, 'Wanneer domino's val: Een na die ander Christen-konsep sneuwel', Beeld, 21 November, bl. 17

Joubert, S., 2009, Jesus: ' $n$ radikale sprong. Christelike Uitgewersmaatskappy, Vereeniging.

Kennedy, P., 2006, A modern introduction to theology: new questions for old beliefs, I.B. Taurus, London.

Klopper, F., 2005, '4000 jaar van soeke na God', Hervormde Teologiese Studies 61(4), 1253-1272. http://dx.doi.org/10.4102/hts.v61i4.486

König, A., 2001, Die helfte is my nooit oor Jesus vertel nie: 'n nuwe kyk op die een wat jou lewe verander, Lux Verbi.BM, Wellington.

König, A., 2009. Die Evangelie is op die spel: die verwarring oor die Bybel, en oor Jesus se lewe, sterwe en opstanding: 'n alternatief op liberalisme en fundamentalisme, Lux Verbi.BM, Wellington.

Küng, H., 1967, De Kerk, Paul Brand, Hilversum.

Leatt, J., Kneifel, T. \& Nürnberger, K. (eds.), 1986, Contending ideologies in South Africa, Grand Rapids, Eerdmans.

Lennox, J.C., 2009, God's undertaker: has science buried God?, Lion Hudson, Oxford.

Lennox, J.C., 2011, Gunning for God: why the new atheists are missing the target, Lion Hudson, Oxford.

Licona, M.R., 2010, The resurrection of Jesus: a new historiographical approach, Apollos, Nottingham.

McGrath, A., 2005, The twighlight of atheism: the rise and fall of disbelief in the modern world. Random House, London.

McGrath, A. \& McGrath, J.C., 2007, The Dawkins delusion? Atheist fundamentalism and the denial of the divine, InterVarsity Press, Downers Grove II.

McLaren, 2010, A new kind of Christianty: ten questions that are transforming the faith, Hodder \& Stoughton, London.

Manenschijn, G., 1988, Geplunderde aarde, getergde hemel: ontwerp voor een christelijke milieu-etiek, Ten Have, Baarna.

Mulder, F., 2011, Opgestaan: studente se stryd om geloof by Tukkies in die jare 2001-2006, Opgestaan, Cambridge Publikasies.

Müller, J., 2006, Opstanding, Lux Verbi.BM, Wellington.

Müller, J., 2011, Om te mag twyfel: 'n gelowige se reis, Tafelberg, Kaapstad.

Muller, P. (red.), 2002, Die Nuwe Hervorming, Protea Boekhuis, Pretoria.

Nolan, A., 2006, Jesus today: a spirituality of radical freedom, Orbis Books, Maryknoll.

Nürnberger, K., 2010, Richard Dawkins' God delusion: a repentant refutation, Xlibris, London. 
Pellencin, A.L., 2007, Ateïsme: die saak teen God, Publiself, Pretoria.

Pienaar, A., 2010, Saam op soek na God: soeke na'n eietydse spiritualiteit, Griffel, Kaapstad.

Potgieter, R.M., 2002, 'Keith Ward and Panentheism: an evaluation of Keith Ward's panentheism as a step towards a model for a Christian interpretation of cosmology', Ph.D. thesis, Potchefstroom University for C.H.E.

Republiek van Suid-Afrika, 1996, Die Grondwet van die Republiek van Suid-Afrika (Wet 108 van 1996), Staatsdrukker, Pretoria.

Retief, F.P., 2002, 'Omgewingsbestuur vanuit 'n Christelike lewensbeskouing - riglyne vir volhoubare ontwikkeling', Koers 67(2), 177-193. http://dx.doi.org/10.4102/ koers.v67i2.368

Russell, B. [1957] 2002, Why I am not a Christian - and other essays on religion and related subjects, Routledge, London.

Schutte, F., 2008, Jesus' resurrection in Joseph's garden: a postmodern revisit, Protea Boekhuis, Pretoria.

Schutte, F., 2010, Diaspora van die nuwe Christene, Griffel, Kaapstad.

Smit, D.J., 2007, Essays in Public Theology: Collected essays 1, Sun Press, Stellenbosch, (ed. E.M. Conradie).

Spangenberg, I.J.J., 1998, Perspektiewe op die Bybel: God se Woord in mensetaal', Van Schaik, Pretoria.

Spangenberg, I.J.J., 2009, Jesus van Nasaret, Griffel, Kaapstad. (Met medewerking van Pieter Botha en Maretha Jacobs.)
Stott, J., 1990, Issues facing Christians today, Marshall Pickering, London. Van Aarde, A., 2001, Fatherless in Galilee: Jesus as Child of God, Trinity, Harrisburg. Van der Watt, J. (red.), Joubert, S., Tolmie, F. \& De Villiers, P. 2010, Wie sê julle is Ek? Jesus deur die oë van ander, Christelike Uitgewersmaatskappy, Vereeniging.

Van Wyk, J.H., 1984, Calvyn oor die Christelike lewe, NG Kerkboekhandel, Pretoria. Van Wyk, J.H., 1986, Gesindheid en gestalte, NG Kerkboekhandel, Pretoria.

Van Wyk, J.H., 2009, 'Laat julle lig skyn - oor etiese kwessies van die dag.', in J.M. Vorster (red.), Uit Dankbaarheid 1959-2009: die gereformeerde kerke in SuidAfrika, bl. 153-161, Gereformeerde Kerke in Suid-Afrika, Potchefstroom.

Vorster, J.A., 2006, 'Waar is God? Relevante insigte in die Westers-Christelike tradisie rakende hedendaagse bevraagtekening van God se teenwoordigheid', Hervormde rakende hedendaagse bevraagteken
Teologiese Studies 26(1), 175-173.

Vorster, J.M., 2004, Ethical perspectives on human rights, Potchefstroom Theological Publications, Potchefstroom.

Vorster, J.M., 2007, Christian attitude in South African Liberal Democracy, Potchefstroom Theological Publications, Potchefstroom.

Vorster, J.M., 2008, The challenge of contemporary religious Fundamentalism, Unisa, Pretoria.

Vorster, N., 2007, Restoring human dignity in South Africa, Christian anthropology in a new dispensation, Potchefstroom Theological Publications, Potchefstroom.

Wessels, F., 2006, Wie was Jesus regtig? Oor die historiese Jesus, Lux Verbi.BM., Wellington. 